\title{
A Stakeholder Analysis of the Development of a Large-Scale Professional Development Program
}

\author{
Ola Helenius | ORCID: 0000-0002-0609-7064 \\ Department of Pedagogical, Curricular and Professional Studies, \\ University of Gothenburg, Gothenburg, Sweden \\ ola.helenius@ncm.gu.se
}

\begin{abstract}
The development of a large-scale professional development project for Swedish mathematics teachers is retrospectively examined. By referring to documentation produced by stakeholders in the development process, the stakeholder's design recommendations and underlying assumptions on teacher development are described. Seeing the development as a co-determination process explains how research-based principles appearing early in the process gradually change to become something different in the end, without the reasons for this shift ever being explicitly discussed in stakeholders' documentations. It is discussed whether the distributed way of constructing the program might cause difficulties in sticking to an explicit theory of change.

The impact sheet to this article can be accessed at 10.6084/mg.figshare.16610113.
\end{abstract}

\section{Keywords}

mathematics - teacher professional development - implementation - large-scale

\section{Introduction}

Sweden was the first country to stipulate by law that education must be research-based (Bergmark \& Hansson, 2021). Therefore, it is not a far-fetched idea that professional development programs should also be research-based, particularly when initiated by the government. In the present paper, I examine the development of a Swedish national-scale professional development (PD) 
program for mathematics teachers entitled Boost for Mathematics ${ }^{1}(\mathrm{BfM})$. This case is interesting from an implementation perspective because of the multitude of stakeholders involved in the development of the PD. In simple cases of implementing educational innovations, the only professional stakeholder groups might be researchers and teachers. In the case of extensive programs like BfM, the set of stakeholders can be extensive and include the government, national authorities, local politicians and school leaders, principals, and so on, all affecting or affected by the program's implementation. However, the particular issue of interest in the present paper is the multitude of stakeholders involved in the development phase of BfM.

As I will describe when reviewing the research conducted so far on BfM, whether BfM builds on a coherent theory of change has been called into question (Jankvist et al., 2021). Jankvist and colleagues base their argumentation on an examination of four phases in the implementation of BfM: the policy and organization phase, which partly overlaps with the development phase, the actual implementation phase, and the evaluation phase. Most importantly, Jankvist and colleagues build on an in-depth analysis of the content and research base for one of the so-called PD modules in BfM. They analyze how this content was chosen relative to the theory of change intended by the stakeholders responsible in the organizational phase. In the present paper, I instead look closer at the planning and organizational phase and the relations between stakeholders involved in this phase. The research question explored is how a multi-stakeholder scenario might affect the implementation of educational innovations in the form of a PD, with a specific focus on the planning stage. The exploration of my research question will be done by examining the single case of BfM. The aim is to explain some interesting phenomena in implementation processes but leave it to the reader to judge their potential importance and generality. The paper also aims to overview BfM and the research conducted on this program so far. In itself, this latter objective is worthwhile from an implementation point of view due to BfM being somewhat unique in terms of its national impact.

By reviewing documentation produced during the program's construction, I will show how the ideas for the program shifted over time and between stakeholders. To allow such shifts to be detected and described, I will invoke the language of praxeology from Chevallard's Anthropological Theory of the Didactic (ATD).

The article is structured in the following way: First, I will present the main elements of BfM in its finished form and how it is set in the Swedish school

1 The Swedish name is Matematiklyftet and the translation "Boost for Mathematics" is the one used by the Skolverket, the Swedish National Agency for Education. 
system. This is important because the institutional organization of the school system, including its governance, frames how a PD can be constructed. I will then present previous research on the BfM. This is followed by a presentation of the basic elements of ATD and how it has been operationalized to suit my aim. I will then go through the development stages of the BfM and describe how to understand the different stages in terms of components of a praxeology, and then compare differences across stakeholders. Finally, I discuss the results from an implementation research point of view and present my conclusion.

\section{The Structure of the Swedish School System and the Boost} of Mathematics

The state governs the school system in Sweden: education legislation, curricula, school inspections, and other support systems are administered by the state on a national level. However, each school is organized by what I refer to in this paper as a School Administrative Body (SAB), which is either a municipality, company, or non-profit organization. By law, SABs are responsible for the teachers, teaching quality, and teachers' professional development. It is important to know that the Swedish governmental system has a high power distribution. Government departments are small, and ministers (typically the heads of departments) are explicitly forbidden to exercise direct power. Instead, Sweden uses a system of state authorities and agencies. One such agency is the Skolverket (the Swedish National Agency for Education). The Minister (Secretary) of Education can give assignments to the Skolverket but does not directly influence how assignments are interpreted or implemented, causing a ping-pong effect between stakeholders during the development of BfM.

The government and the Skolverket do not formally decide on teachers' professional development, but they can develop and offer supporting materials and economic assistance for SABs. This was precisely the organizational structure of BfM. The Skolverket offered a set of professional development web modules on their website. From 2013 to 2016, SABs could apply for financial support from the state, channeled through the Skolverket, teachers attending BfM, and resource persons acting as group leaders in collaborative work. Teachers from any school in Sweden, from preschool (children from one to five years of age) to upper secondary school (children from 16 to 18 years of age), were invited to attend, should their SAB choose to participate. Financial support, which was not granted to preschools, was provided for only one year of attendance, but SABs could allocate more time if wanted or needed. The materials for PD were freely available on the Skolverket's website without any login or registration procedures required. 
The pedagogical model of BfM assumed groups of approximately four to eight teachers working together in study groups with a local advisor. Typically, this advisor was a skilled teacher who had to be working with BfM at a minimum of $50 \%$ of their workload, and who received training specific to the advisory role within the BfM framework. Teachers were grouped according to their taught grade, divided into the following grade ranges: 1 to 3,4 to 9,7 to 9 , or 10 to 12 . Modules were designated specifically for each range. There were also modules for other forms of school that do not fit within this classification.

The material was structured as several different web modules still available on the Skolverket's designated webpage, despite the formal PD program ending in 2016. Modules could both be labeled by subject matter, like algebra or number sense, or in some other way like "Mathematics Teaching with Digital Tools." One module took around half a year to complete, with teacher meetings held most weeks. More specifically, almost all modules were composed of eight chapters, and every chapter was composed of the same cycle of four sessions. Session A consisted of individuals studying PD materials in text or video format focusing on specific study questions. Session B was a collaborative meeting to compare reflections on the studied material and plan a teaching activity, with more or less guidance from instructions in the module materials. Session C consisted of conducting the activity, which might be one lesson or part of a lesson, with their students. Session D was a collaborative follow-up group meeting. Typically, one group meeting (B or D) met every week, making the module approximately 16 weeks long. In practice, this amounts to work over one semester.

The modules were developed by different research teams and teacher educators. Typically, such a team had to include members from three different universities. The Skolverket used a relatively standard contract to regulate the design of the modules. In addition to describing the standard module structure described above, the construct also stipulated that four so-called didactical perspectives should be treated in each module. These were formative assessment, sociomathematical norms, classroom interaction, and teaching in accordance with competencies. The last perspective refers to the competence ${ }^{2}$ goals in the Swedish national curricula. The teaching should be devised to help pupils develop these mathematical competencies specified in the curricula. It typically took half a year to develop a module. Two times during the process,

2 The Swedish equivalent is förmågor. The word could be translated as skills, but "förmågor" is the specific term in the national curriculum that designates the type of goals that are the called proficiencies in Adding it up (Kilpatrick et al., 2001), process goals in NCTM standards (National Council of Teachers of Mathematics, 2000) or competencies in the Danish framework developed by Niss and Jensen (2002). Since the goals in the Swedish curricula are closest to the Danish variant, I use the translation "competencies". 
there was a peer review carried out where, typically, other module developers and the Skolverket assessed the quality of the work and its alignment with the BfM structure.

\section{Previous Research on the Boost for Mathematics}

So far, research and evaluation of BfM have been of four general types: (1) studies on the effect at the student level; (2) studies on the effect on the teacher and teaching; (3) studies on the content of the PD modules; and (4) more general studies where BfM is used as a case and where different aspects of the theory of change, i.e., the theory by which one understands the changing behavior of teachers, is examined. Below, I will review some examples of each type.

\subsection{Effects on Students}

The first type of research concerns the effects of BfM on the level of student achievement. Interestingly, the implementation of BfM did not include a structure to evaluate the effects on the student level. Sweden has a national test system, but it is not well suited for such follow-up since the difficulty level differs between years. Therefore, other types of testing had to be utilized to evaluate the effects on the student level. Up to this point, only two studies managed to examine the effects of BfM on the student level. Lindvall et al. (2018) used the fact that a large municipality in Sweden ran a PD program of their own in parallel with BfM, where number sense tests were administered (McIntosh, 2008). Since all teachers in the municipality started with one of the number sense BfM modules, this test should be relatively well suited to detect changes at the student level. The authors concluded that, when compared with the control group of pupils of teachers that, up to this point, had not gone through BfM, pupils of BfM teachers showed slightly better results. Still, the differences were only significant in grades 4,7 , and 8 , and the effect sizes were small (partial $\eta^{2}$ between 0.005 and 0.027 ). Lindvall et al. (2021) utilized the fact data collection of Timss (Trends in Mathematics and Science Study) 2015, which was done when roughly half of the Swedish teachers had completed BfM. Data on teacher participation in BfM was noted in the TIMss teacher survey. By calculating class means for the TIMss mathematics tests and comparing results between classes taught by attending and non-attending teachers, the researchers concluded that no significant effects of BfM could be seen on the student level, either in grade 4 or grade 8 , which are the two grades where TIMss is administered. Based on both of these studies, it does not seem that BfM has a significant impact on students' performance. 


\section{2 $\quad$ Effects on Teachers and Teaching}

To note, it is generally hard to get detectable effects of large-scale PD on the level of student achievement, and effect sizes are generally small (Hill et al., 2008; Kennedy, 2016). Yet, the null result on the student level questions whether some particular aspect of PD has failed. In implementation research, the theory of change denotes "[...] a collection of theoretical constructs that may be used to guide the design and implementation of a program, and to evaluate its success or failure" (Jankvist et al., 2019, p. 2). In PD research, the corresponding concept is often called a program theory. It is often divided into two components: the theory of instruction, involving concepts such as instructional design, principles, and knowledge that the teachers are supposed to acquire in PD; and the theory of teacher change, involving the pedagogy and activities in PD that are supposed to lead to the teachers changing in line with the theory of instruction (Wayne et al., 2008). When PD does not give results on the student level, one can ask: Is the theory of instruction wrong, or is the theory of teacher change not functional?

The Skolverket hired the evaluation consultant firm Ramboll to do several evaluations of $\mathrm{BfM}$, which was both summative and formative in the sense that early indication was used to fine-tune certain aspects of BfM. Ramboll mostly collected and analyzed data through interview-based case studies of collaborative teacher meetings and large-scale questionnaires. In their final summative report, they concluded that BfM worked very well on a program level and teacher level in the sense that it contributed to a developed teaching culture and professional development culture (Ramboll, 2016). A developed teaching culture was operationalized as follows: "[...] teachers that have participated in $\mathrm{BfM}$, to a higher degree, reflect on their own teaching, obtain more teaching methods, increase their mathematics education knowledge and increase their engagement in collegial learning" (Ramboll, 2016, p. 9, my translation). This is a very general way of understanding the expected effects of BfM on teachers.

Instead, Lindvall et al. (2021) used the teacher and student reports from TIMSS on the frequency of particular teaching behaviors. They classified them into behaviors in line with the BfM theory of instruction or not. The researchers showed a positive and significant correlation between BfM participation and teaching in line with the BfM theory of instruction with an effect size of 0.3 standard deviations. This conclusion is supported by Österholm and colleagues (Österholm et al., 2016), but they investigated the issue more intricately. First, they based their analysis on classroom observations of teachers before, during, and after their BfM participation, which is generally considered more reliable than teachers' reports. Second, the observational framework was also designed to focus on four didactical perspectives that every module, regardless of content, was supposed to treat. Österholm et al. concluded that 
"BfM has had a clear and lasting effect on teachers' planning, reflection, and implementation of teaching. Therefore we recommend continued usage of the arrangement of teacher professional development that has now been used in BfM" (p. 44).

Summarizing the above, BfM has so far shown very small or non-existent results on the student level, even though there seems to have been an effect on teaching. Therefore, it makes sense to look at research that has examined the content of BfM more closely.

\subsection{The Content of the Modules}

Lindvall et al. (2018) compared BfM with another large-scale PD driven by a large municipality. They concluded that both programs were very similar in structure because both were aligned with principles often considered state of the art in large-scale PD, e.g., the five principles from Desimone (2009). To distinguish the two programs, they developed a framework where they categorized the content of the primary and secondary school modules on number sense (which is the module almost all teachers chose as their first module) in terms of two types of teacher knowledge, two types of teacher practices, or reflections on one's learning. They found that teacher knowledge accounted for $62 \%$ of the content of the modules, teacher practices $31 \%$, and reflection of one's learning $15 \%$ (Lindvall et al., 2018). Lindvall et al. also used Kennedy's characterization of PD programs according to four methods for facilitating teacher enactment: prescription (prescribing teachers what to do), strategy (providing teachers with multiple strategies to choose from, including a rationale for why to use them), insight (raising provocative questions for teachers to get new insights about their instructional practices), and body of knowledge (presenting teachers with a body of knowledge without stimulating particular teacher actions). They found that for module content concerned with teacher actions, $79 \%$ of the activities were of the insight type and $21 \%$ of the strategy type. For the content category lesson design, $71 \%$ were strategy and $29 \%$ insight. Lindvall and colleagues speculate that one reason that BfM had small or non-existent effects might be that the theory of instruction of BfM requires a relatively complex change in teaching behaviors. It might have been better if the content, to a larger degree, concerned teacher practices, where the content concerning teacher action is facilitated more in terms of strategies than insight.

Lauridsen and Gregersen (2017) also analyzed modules and used a similar Kennedy-based method on two different modules for grades 7 to 9: algebra and problem-solving. Similar to the number sense modules, the algebra module mainly relies on insight in Kennedy's sense. In contrast, the problem-solving module comes out as relying mainly on strategy. The problem-solving module 
is also far more devoted to teaching the teachers a particular teaching model, namely the five practices model for problem-solving teaching of Stein and colleagues (Stein et al., 2008). Overall, Lauridsen and Gregersen make several other types of analyses of the two modules. Interestingly, the two modules come out as quite different, as this indicates that the instructions from the Skolverket to the module developers were probably quite relaxed.

\subsection{The Structure of BfM and Its Theory of Change}

To some extent, Jankvist and colleagues (2021) explain the variance between modules: they examined the same algebra module as Lauridsen and Magaard in greater detail and interviewed the researcher who led the algebra module's development team. Jankvist et al. analyzed the algebra module and its place in BfM from a theory of change perspective. They concluded that the theory of change for BfM, developed by the Skolverket and NCM, was not communicated clearly to the developers of the modules, at least not to the algebra module developers. This allowed the algebra module developers to practically devise their own theory of change and build the module on variation theory (a learning theory with roots in phenomenography, see Marton \& Booth, 1997), despite the Skolverket themselves explicitly stating in their preliminary work (Skolverket, 2012b) that no specific learning theory should have too much impact in any given module (Jankvist et al., 2021). Another enabling factor for the algebra module's deviation was that its development started quite early before the structure of the modules was set entirely. However, this does not explain the variation between other modules. It is reasonable to agree with Jankvist et al. that the theory of change, including how the modules should deal with the four didactical perspectives, was not communicated clearly (2021).

Another aspect of BfM's theory of change concerns the general setup with so-called collegial learning, the use of local resource persons, a multitude of web modules, the involvement of principals, and so on. Boesen et al. (2015) analyzed the creation of the BfM by analyzing much of the same documents that I will also review in this paper. They conclude that while much of the relevant research on large-scale PD was referred to in the planning documents from the government and the Skolverket, the actual decisions were seldom anchored in actual research results from the referenced literature. So the structure of the program generally complied with the state-of-the-art in large-scale PD research, but it was unclear how this structure was determined.

Kirsten and Carlbaum (2020) used BfM as an example to study the Swedish phenomenon entitled collegial learning. As mentioned, collegial learning is the term adopted by the Skolverket when implementing PD in the form of collaborative teacher work into BfM. As Kirsten and Carlbaum note, the 
terminology was virtually undocumented before BfM. Kirsten and Carlbaum note that searches in media databases reveal that before BfM, the term collegial learning ${ }^{3}$ was non-existent. Still, from 2011 to 2019, during and after BfM, Kirsten and Carlbaum found almost 3000 articles mentioning the term. In Swedish scientific databases, this trend is even more apparent (Kirsten \& Carlbaum, 2020).

After a rather radical school reform in Sweden in the 199os (Haldén, 1997), teacher PD was mostly locally organized, even with economic state support. Kirsten and Carlbaum remark that BfM marked a shift towards externally initiated PD where, at least in the case of $\mathrm{BfM}$, the local choice is limited to organizational issues and the choice of PD module for implementation. Kirsten and Carlbaum conclude that this is a shift in the view of teacher professionalism away from an idea of extensive autonomy (Kirsten \& Carlbaum, 2020).

This compares interestingly with Prytz's (2021) results. He compared BfM with the implementation of New Math in Sweden in the 196os from a governance and research implementation perspective. The historical perspective of Prytz is hence much longer compared to the perspective of Kirsten and Carlbaum. Prytz sees a move towards decentralization, in particular regarding the content of the PD program. Within New Math, a general hypothesis on teaching and learning based on a chosen perspective was formulated nationally and eventually implemented with teachers at scale. This was also the construction mode of another program run during the 1970s and 1980s reviewed by Prytz. With BfM, however, only the PD structure and some aspects of the content were decided centrally. Then it was up to individual module development groups to fill in the gaps (Prytz, 2021). As I have noted, this led to a lot of variation between modules that can be interpreted as a lack of one central theory of change that permeates the PD as a whole (Jankvist et al., 2021).

In summary, both the PD modules themselves and the documentation concerning how BfM was designed have been analyzed in different ways by several scholars. There is a relatively coherent picture of how BfM worked and what $\mathrm{BfM} i$ s, and partly what could, and maybe should, have been different. To date, the documentation from stakeholders involved in creating BfM has been analyzed as a totality, which means there is an implicit assumption that the stakeholders created BfM collaboratively. I will not make that assumption and instead analyze the contributions from each stakeholder in its own right with the aim of making a comparison of similarities and differences. To operationalize this idea, I will use the Anthropological Theory of the Didactic, which includes the concept of co-determination, which is the idea that knowledge objects in formalized education (in our case, professional development of

3 The Swedish term is kollegialt lärande. 
mathematics teachers) are influenced by several layers of societal institutions in, perhaps, different ways (Chevallard \& Sensevy, 2014).

The Anthropological Theory of the Didactic (ATD) is concerned with didactics in the general sense of a science of knowledge diffusion. Within the theory, one stipulates a knowledge object, $\mathrm{O}$, to be learned by some human, $\mathrm{x}$, possibly some group of humans, $X$, and possibly with the help of some human (teacher), y, from some group, Y. What makes the theory anthropological is that $\mathrm{O}$ is considered as a set in a hierarchy of societal arrangements from the whole of humankind itself through societies, schools, pedagogies, disciplines, themes, subjects, and so on. A specific person or group does not determine $\mathrm{O}$. It happens through a type of equilibrium, a co-determination process where the levels in the presented hierarchy socially and historically frame the object (Chevallard \& Sensevy, 2014).

Within ATD, a knowledge object O (sometimes called work or stake) is understood as a structure of four components. The first of these is called the task type, $T$, which is some objective the learner can work on. Associated to $T$ are a set of techniques, $\tau$, that a learner can potentially engage with to perform tasks of type $T$. In some sense $(T, \tau)$ is the simplest possible element of teaching, and it is sometimes called the praxis block. We want some individuals to be able to deal with tasks of some type eventually. We can introduce such tasks, vary their difficulty within the type, let the person get acquainted with techniques to handle the tasks in some way or the other, and construct examinations with tasks of the type and expect them to be treated with the relevant techniques. "Dealing with tasks of type $T$ " can be put in curricular documents and so on.

The praxis pair $(T, \tau)$ does not determine a knowledge object alone. The relevant techniques to treat tasks in $T$ benefit from being discussed in a broader sense. Why do they work? How do the relations look between techniques in $\tau$ and techniques in $\tau^{\prime}$, both relevant for treating tasks of type $T$ ? In praxeology theory, such an overarching discourse on techniques is called a technology and is denoted by $\theta$. A word of caution about the term technology is in order. It should not be associated with technical artifacts but rather with symbolic technology. Finally, to complete the quadruplet of knowledge elements, a category theory, $\Theta$, is considered. The term theory here is used in a general sense as a system of organizing principles over the more pragmatically oriented technology category. $(\theta, \Theta)$ is often called the logos block (Chevallard et al., 2015). 
In the sense presented above, the system can be thought of as a sequence: you have a task; you develop a technique; you explain its validity and set it in an organizing system of principles. However, the reverse direction is often more interesting. The logos block determines what practices make sense and why certain practices are relevant and important. This means that the logos block is not just a retrospective organization of praxes. In a co-determination system where the logos are relatively set, they will also act ideologically on the set of possible practice blocks.

In my application, I will use the idea of praxeology to analyze how the stakeholders involved in the developmental stages of BfM envision the PD praxis, meaning that the knowledge object will be some form of teacher knowledge related to mathematics teaching. The praxis block will concern some tasks for the teacher, in terms of reading some text, carrying out some teaching activity, having a discussion with colleagues about some didactical phenomena, and so on. The different stakeholders involved in creating BfM will be considered as institutional levels involved in a co-determination process. Since I'm reviewing different stakeholders' ideas about program construction and their associated rationale, I will designate the technology category, $\theta$, for the stakeholder's argument for why particular PD praxis would be beneficial for mathematics teachers, meaning that it will ultimately lead to better teaching. I will use the theory category, $\Theta$, for when stakeholders explicitly argue from a research-based perspective to include some particular praxis in the PD. This interpretation of $\Theta$ breaks with the original sense adopted in ATD but will offer a practical nomenclature for my purposes, as will be described in the Method section below.

The approach I will take is to analyze documentation available from different stakeholders involved in creating BfM with a particular focus on the early stages. I will look at seven steps and analyze them through documentation released by the stakeholder responsible for that particular step. The final steps will be actual modules in the finished version of BfM. For each document, I will bring together my reading of the document and previous research analyzing the document to support my reading. I will first give a brief description of the document and the arguments it entails and then extract six pieces of information related to different components of a praxeology as described in the theory section above. I will first review which category $(\mathrm{X})$ of professionals are positioned as learners (e.g., teachers, principals, mathematics advisers) within the $\mathrm{PD}$. The next category $(\mathrm{Y})$ concerns persons who are positioned as enablers 
of learning. In standard teacher education, the teacher educators would be in category Y. However, I will also allow myself to classify material resources described as fundamental for the PD in category Y. In such cases, material texts or videos are considered to have agency in the PD much in the same way as Latour (2005) uses agency in actor-network theory. I then analyze what kind of tasks $(T)$, as described by the stakeholders, the PD is supposed to enable learners $\mathrm{x}$ to carry out. I designate the technique category $(\tau)$ to denote the type of activities the stakeholders suggest for $\mathrm{x}$ to learn or practice $T$. The technology category $(\theta)$ will denote the arguments the stakeholder presents when arguing for why $(T, \tau)$ is appropriate praxis for the PD. I reserve the theory category $(\Theta)$ to denote the research base or other literature-based stakeholders referred to to support their arguments.

\section{6}

A Praxeology Analysis of the Construction Phase of BfM

The seven stages in the development process of BfM I will analyze can be seen in Figure 1. The stakeholders, the Skolverket and the government, are represented twice. Still, as ideas on BfM change over time, it makes sense to analyze documents presented at different points in the developmental process separately.

\subsection{Presentation from the National Center of Mathematics Education for the Minister of Education 101129}

The National Center of Mathematics Education (NCM) in Sweden was established in 1999 by the government. Its main financing comes from the government, channeled through the University of Gothenburg. The NCM is positioned as a special unit at the central administration at the university and is not connected to any particular faculty. The documentation for this stage of the development of BfM comes mainly from email conversations between persons at the NCM and the department of education. In October 2010, the NCM was contacted by the Department of Education and asked to prepare a suggestion of how to develop mathematics teaching and learning in Sweden. The NCM was

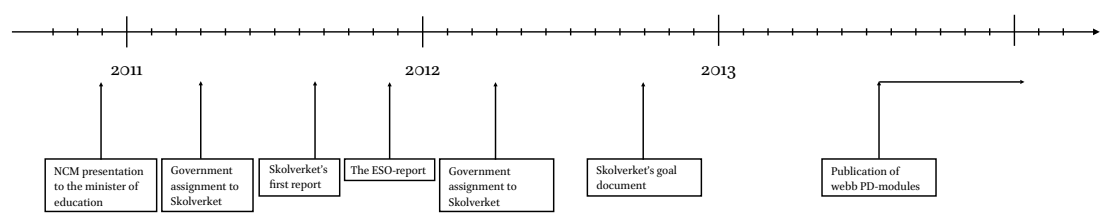

FIGURE 1 A timeline for stakeholder influence on BfM 
asked to present the ideas to the minister of education, Jan Björklund, at a meeting held at the end of November the same year. The core of the suggestions from the NCM was to develop a guiding material building on the different national curriculum documents. In 2004, a mathematics delegation initiated by the government had already described that Swedish mathematics teaching was too limited to the pupils working in the book (Utbildningsdepartementet, 2004). The school inspectorate and researchers had seen that teaching only gave pupils limited possibilities to develop the mathematical competencies that, since 1994, was a core part of the national curricula (Boesen et al., 2014). An important aspect of the teacher guide suggested by the NCM was to develop a teaching model that would help pupils develop mathematical competencies. At the time, NCM was developing such teacher guidance material for preschool classes, that is, for teachers of six-year-old children. The research background for that project was a review of previous interventions for six-year-olds, particularly in the concrete-representational-abstract (CRA) teaching model introduced by Witzel et al. (2003). The teacher guide (Sterner et al., 2014) was developed in a design research project (Sterner \& Helenius, 2015) and later evaluated in a randomized control trial (Sterner et al., 2020).

The NCM envisioned a dedicated steering group, independent from the Skolverket that, in turn, administered special development and professional development teams. It was considered that relatively small groups of researchers and teacher educators could develop the guides, presenting the work at conferences with a peer review system consisting of other researchers to gain acceptance for the model. It should be noted that NCM also wanted teacher educators to be included as learners in the program, indicating a view that teacher education was also seen as part of the problem.

\subsubsection{A Praxeology Interpretation}

The NCM describes teachers and principals, school leaders and politicians, and teacher educators as learners $(\mathrm{X})$. Loosely, they reason PD teams as enablers $(\mathrm{Y})$, but there is no discussion on which categories of people would comprise the teams. More importantly, the main suggestion by the NCM revolves around a teacher guide developed by an expert group of researchers and educators. The guide would then act as an enabler in the sense of being an agent of the developers $(\mathrm{Y})$. The task for the teachers set out by the NCM would be to use the teacher guides as bases for teaching. Together with the focus on teaching to develop the competencies, we can say that the imagined task (T) for the teachers is to develop teaching that develops pupils' mathematical competencies. The techniques $(\tau)$ suggested are practice-based local collaborative sessions involving teacher and teacher educators where the material is studied and used. The 
technological aspect $(\theta)$ in the NCM's suggestion builds on a more detailed description of teaching than what is available in the national curricula, which would help teachers improve their teaching. The literature base $(\Theta)$ for the NCM's suggestions are mainly reports and research grounded on the school inspectorate's reports and associated research (Bergqvist et al., 2010a, 2010b; Boesen et al., 2014).

\subsection{Governmental Assignment $11033^{1}$}

Since the government in Sweden has relatively low levels of formal power, once they had decided that large-scale professional development for mathematics teachers should be arranged, the next step was to give assignments to the relevant authorities, namely the Skolverket. The instruction to the Skolverket is very short, about half a page, followed by around one and a half pages where the arguments behind giving the assignment are presented. The assignment states that "Skolverket should investigate and propose how a didactical professional development for all mathematics teachers should be accomplished" (Regeringen, 2011, p. 1, my translation). The government states that the purpose of the professional development project should be to increase pupils' attainment of educational goals by strengthening the quality of teaching and that PD should give teachers support and inspiration to develop classroom activities that give pupils better chances to develop knowledge and competencies and teachers concrete support and inspiration to develop and try out teaching models based on research and proven experience. It is also stated that PD should be close to practice and actively involve teachers. The government also specifies that the PD should be based on a material component but does not mention anything about PD being based on support by external experts. It is stated that the Skolverket should collaborate with the NCM to make an inventory of existing material that could be used as support material for teachers and in the PD. In areas where existing material is missing or incomplete, the production of complementary material should commence. It is also stipulated what the role of the material should have: "The material should stimulate further reading, reflection, competence development, and collegial cooperation between teachers in planning, implementation, and follow-up while contributing to a development of their teaching" (Regeringen, 2011, p. 1, my translation). This suggests a somewhat different material than the teaching guides suggested by the NCM.

As a basis for its decision, the government refers to reports from the educational agencies, such as, for example, the School Inspectorates reports on the status of mathematics teaching in Sweden (Statens Skolinspektion, 2009, 
2010). In particular, the government argue that an area of improvement for teaching in Sweden would be to develop teaching that in a better way that helps students to develop their mathematical competencies manifested in the national curriculum.

\subsubsection{A Praxeology Interpretation}

The government focuses clearly on teachers as learners in PD (X) and study material for teachers to use as inspiration as the enabling component $(\mathrm{Y})$. The tasks $(T)$ set for the teachers is to develop and use classroom activities that give pupils better opportunities to develop knowledge and competencies in line with the goals in the new curricula, and the technique $(\tau)$ suggested for achieving this is collaborating with colleagues and implementing teaching models. The technology $(\theta)$, or ideology underlying this praxis, is that by studying didactic support material with colleagues, teachers will be inspired to change their teaching by developing teaching models better suited to allow pupils to develop the competencies specified in the national curricula. The research support $(\Theta)$ that is cited is mostly reports from Skolverket and the School inspectorate (e.g. Statens Skolinspektion, 2009, 2010).

\subsection{The Skolverket Report 110729}

The Skolverket ${ }^{4}$ spent around four months investigating how a large-scale PD program for mathematics teachers should be arranged and presented the conclusions in a 40-page report consisting of one page with specific recommendations and a 39-page document that details the recommendations, including the financial requirements and the basis for the recommendations (Skolverket, 2011). This report has previously been analyzed in detail by Boesen et al. (2015), so I will summarise the most important information here. In this report, some detailed aspects of the final version of BfM appear for the first time, including ideas that did not get implemented. In this report, the Skolverket introduced the term collegial learning when describing that the main organizational principle for BfM should be collegial learning with resource persons. The resource persons are given the name mathematics advisors. Collegial learning refers to PD collaborative local teacher work in the sense described by Timperley (2007) with two important changes. First, the external experts instrumental in

4 According to the government assignment, the Skolverket should collaborate with the NCM in the development of BfM. Since the Skolverket had the responsibility I will not mention this collaboration further and not try to evaluate any eventual influence from the NCM on the Skolverket's analyzed contributions. 
the model that Timperley describes as effective have been replaced by a local resource person who should be educated within BfM and work as a resource person at least half the time. Second, the expert role has been taken over by a material that is to be provided in web-based modules. As Kirsten and Carlbaum also note, it is here that the shift from external expert support to "mathematics advisor" is made. The mathematics advisors were not external experts but local teachers who received some short educational support within the BfM structure, focusing on how to administer the collaborative teacher discussions (Kirsten \& Carlbaum, 2020).

The Skolverket also introduced the idea of producing a multitude of modules that SABs or schools can choose from, inspired by the German sinUs project (Ostermeier et al., 2010). In doing so, they solve several problems. The Skolverket can claim that the program is not fully centralized since choices can be made at the local level. By allowing such choice combined with the collaborative setup, the Skolverket argues that teachers can feel that they are codrivers of their PD, not just passive recipients. As Kirsten and Carlbaum note, this construction allows the Skolverket to, at the same time, offer local flexibility as well as equal opportunities to all SABs (Kirsten \& Carlbaum, 2020). The module design also allows Skolverket to distribute the responsibilities of producing the material over more universities, again a form of decentralization.

\subsubsection{A Praxeology Interpretation}

Skolverket specifies both teachers and principals as learners in the PD (X). They suggest the enabling component $(\mathrm{Y})$ to be a selection of web-based PD modules. The task $(T)$ is described as developing better teaching by being connected to the (at the time) new national curricula, which relied extensively on the notion of mathematical competence. The task $(T)$ also includes developing knowledge on learning theories and pupil's misconceptions, teaching methods, and assessment. The technique $(\tau)$ suggested for achieving this is reading or watching material from web-based PD modules, discussing with colleagues under resource person supervision, planning activities, trying them out in their class, and following up iteratively. The argument presented $(\theta)$ is that by choosing between different PD modules, the PD can be adjusted to local requirements, and by studying the PD modules in collaborative settings and trying out activities, teachers can develop their teaching to serve students' development of mathematical competencies better. The research base $(\Theta)$ provided is a large assortment of reports on the state of the Swedish school system, mainly from Skolverket themselves and an assortment of mainly PD research; see Boesen et al. (2015) for a description. 


\subsection{The Report by the Expert Group for Studies in Public Economy, November 2011}

The assignment to the Skolverket to explore how a large-scale PD could be designed was issued by the Department of Education. Still, in parallel, the Expert Group for Studies in Public Economy (ESO) located in the Department of Finance worked on their own report. Even though there is no indication of whether this report was written as a preparation for BfM or not, it is worthwhile to include since it is an example of the government's institutionalized efforts to stay connected to research related to different aspects of public administration. The Eso group is situated in the Department of Finance but independently decides what studies to conduct. The report in question is entitled To Learn From the Best - an ESO Report on Swedish Schools from an International Research Perspective (my translation) written by Johannes Åman (Åman, 2011). Relevant for the present analysis is that Åman highlights "the most effective [teacher professional development] programs are those that both engage external expertise and let teachers take part in some kind of community of practice" (p. 20). Åman draws this conclusion by referring to Timperley et al. (2007). Åman, however, continues to describe that the decentralized school system of Sweden poses obvious problems if such programs were to be implemented as a national policy and warns that "[p]olicy makers who choose this path must be aware of the delicacy of the task [...] so complex that the only way to find out is by trying, adjusting and trying again" (p. 2o). Clearly, he states that it is not the state's role to prescribe how teachers should teach or even prescribe which teacher development programs in which to participate. He still sees a national framework of programs as a possibility and that "the central government can require that schools have programs for professional development of teachers and that these programs involve engaging external expertise and letting teachers take part in some kind of community of practice" (p. 2o). Åman also argues that principals are important and should be included in different professional development efforts.

\subsubsection{A Praxeology Interpretation}

The Eso report presented teachers and principals as the target group for learning $(\mathrm{X})$. It is somewhat unclear who would be the enablers of learning $(\mathrm{Y})$. At least this group would include external experts in the sense Timperley (2007) uses the term. Åman specifies that the state should not interfere with how teachers teach, but at the same time specifies using goals and feedback in the teaching as so crucial that the state might make that mandatory content of PD. It hence makes sense to set knowledge of using goals and feedback in the 
teaching as preferred tasks $(T)$. Åman proposes using local collaborative groups of teachers with external support as the way to move towards the desired teaching $(\tau)$ but does not further specify how teachers should deal with the task of implementing goal-setting and feedback using routines or any other teaching tasks. On the logos level $(\theta)$, Åman states that it is the classroom teaching that matters. Teachers should set clear goals and evaluate them. Teaching involving such formative assessment components or other quality teachings can be developed locally if there is external expert support. The national level can pressure the local level to arrange PD in particular ways. The research base $(\Theta)$ is mostly meta-studies on teaching interventions and PD with a specific reliance on Timperley (2007).

\subsection{Government Assignment 120329}

As a result of the Skolverket's report, the government made the formal decision to start BfM. It commissioned the Skolverket to do this in a 4-page document where two pages specified the assignment, and two pages described the arguments for the decision (Regeringen, 2012). At this stage, the government brings in new literature and references compared to its previous document. They refer to the ESO report as well as an analysis from the Institute for Evaluation of Labour Market and Education Policy (IFAU), which is an independent but state-driven institute. This report deals with the achievement results and its economic consequences rather than teaching or professional development (Björklund et al., 2013), so it is not as relevant for the planning of a PD as the ESO report. Still, like the TIMSS and PISA reports that are also referenced, it serves as a background for concluding that the achievement results of Swedish pupils have gone down.

As previously mentioned, the government concludes that the teachers do not lead the teaching to a sufficient degree and that the teaching shows too little variation; unfortunately, "... such teaching can give limited space for reasoning, argumentation, and possibilities to discover connections" (Regeringen, 2012, p. 3). This type of formulation is a direct reference to the competencies in the curricula. So it is reasonable to conclude that whatever choices are proposed for the $\mathrm{PD}$, the intention is that teachers would develop their teaching to better support the development of their competencies.

The government picks up the term collegial learning and explicitly refers to the report from ESO (Åman, 2011): they confirm that it is collaborative work with expert support that has proven effective. However, right after the government picks up on the terminology from the Skolverket and declares that " $t]$ he special PD-effort should be based on collegial learning with professional support in the form of mathematics advisors" (Regeringen, 2012, p. 4, my translation). 
Therefore, it is not clear if the government thinks that mathematics advisors should have actual expertise in mathematics education to this day, or if they consider the model proposed by the Skolverket, where the mathematics advisors are rather educated to work as conversational leaders in collegial learning.

The government followed the suggestion from the Skolverket and asserted that PD should be based on different PD web modules. The government further stated that the content in the web modules should be based on relevant and up-to-date research from different disciplines and the Swedish results in TIMSS and PISA.

The government also explicitly states that the Skolverket should consult all universities and university colleges that arrange teacher education. Interestingly, it is explicitly stated that all, not just some, should be consulted.

\subsubsection{A Praxeology Interpretation}

As before, the target learners for the PD (X) are mathematics teachers and principals. The enabling component $(\mathrm{Y})$ should select web-based PD modules based on up-to-date research from different disciplines. The main task $(T)$ should be to develop more active teaching that better supports the development of pupils' knowledge and competencies. The setting for the preferred development $(\tau)$ is described as collegial learning with expert support from mathematics advisors. The ideology $(\theta)$ behind this is that teachers would improve their teaching, in particular teaching for developing students' mathematical competencies, if they could work collaboratively with didactical support material designed from a wide research base. Teachers' possibility for a choice of modules is also described as important. The literature background $(\Theta)$ are reports from Skolverket and the School inspectorate (e.g., Statens Skolinspektion, 2009, 2010). TIMSS and PISA reports, the IFAU (Björklund et al., 2013) report and the ESO (Åman, 2011).

\subsection{Skolverket Goals 120824}

In late August 2012, the Skolverket issued a formal decision detailing the construction of BfM in a 2-page document (Skolverket, 2012a). The structure of the PD is briefly explained with no new details. It is still described as collegial learning with professional support in the form of mathematics advisors and a specific PD for principals. The PD is still also described as building on didactic support material based on the national curricula, relevant research, and Sweden's results in the latest national and international assessments. The novel aspect of this document is a specification of goals. The goals are specified in two categories: the development of teaching culture and professional development culture. I will not repeat the total twelve bullet points related 
to the goals. Some of them are specifically interesting, though. For example, one states that "collegial learning is used" is a goal both for teaching and PD cultures. This means the collaborative style of local school development that in Timperley's (2007) analysis comes out as one particularly effective method for implementing some teaching intervention now has become a goal in itself. With the addition of a second goal, collegial learning leads to teachers developing and consolidating knowledge in mathematics education in their teaching. Another goal is that "the mathematics teaching should be developed in relation to local needs" (Skolverket, 2012a, p. 1) and that the "knowledge on teaching and students learning is based on research and proven experience".

\subsubsection{A Praxeology Interpretation}

Again, the target learners for the $\mathrm{PD}(\mathrm{X})$ are mathematics teachers and principals, and the enabling component $(\mathrm{Y})$ should be web-based didactical support material. The main task $(T)$ is now to participate in collegial learning that develops teaching, while the technique $(\tau)$ is to participate in collegial learning. The logos $(\theta)$ associated with this now seems to be that collegial learning is a goal assumed to lead to the development of mathematics education knowledge that can manifest in teaching. There are no explicit references to literature in this document.

\subsection{The Finished PD Modules}

In the previous research section, I reviewed research on a few of the modules, and I will only briefly remind the reader of the conclusions. The modules all follow a specific structure with four components that are repeated in eight cycles. Typically, one such cycle might be about mathematical reasoning and another about formative assessment. Each group of module developers wrote a contract with the Skolverket that stipulates this structure but also that modules should treat the four didactical perspectives mentioned in Section 2 of this paper.

As described by several previous research reports, there is considerable variation in many dimensions regarding what research base the modules rely on: modules might refer to some of the author's own work or research literature, and that literature can vary considerably in character and content (Boesen et al., 2015; Jankvist et al., 2021; Lauridsen \& Gregersen, 2017).

The modules are, in some sense, all a result of the general competence development literature discussed earlier, but with a few exceptions (e.g., Mason, 2002). Such literature is not referenced in the modules themselves. An analysis of referenced literature in a selection of modules can be found in Boesen et al. (2015). 


\subsubsection{The Praxeology Interpretation}

The modules target teachers $(\mathrm{X})$ and the enabling component $(\mathrm{Y})$, the combinations of text, video, and instructions in the modules. The tasks $(T)$ vary between modules, while the technique $(\tau)$ is always the same one prescribed by the Skolverket; teachers should read and watch content media, discuss, plan, and carry out teaching activities with their class and follow up on the collegial group. The logos pair $(\theta, \Theta)$ varies between modules.

\section{Summary}

In Table 1, I have summarized the praxeology analyses of the contributions from the different stakeholders, and I will use this table as a basis for extracting similarities and differences across the stakeholder contributions. I will start with areas where most or all stakeholders are in agreement.

First, all stakeholders unsurprisingly focus on teachers and often also on principals. Principals were included in BfM, but I will not discuss this further since I have not dealt with it in the paper. The NCM differs by also including teacher educators as learners, but any other stakeholder does not pick this up.

Another similarity is that all stakeholders, except Eso, share a somewhat remarkable agreement that the main task for teachers is to develop teaching that better supports pupils in developing mathematical competencies. Other tasks (like developing assessment practices) are visible too, but not as strongly as the latter.

There is also a relatively good agreement that the enabling category $(\mathrm{Y})$ cannot be humans (like researchers, teacher educators, or similar). The PD must mainly be based on a web-based material component. The agreement on this is unsurprising given the scale of the PD. A further observation mostly related to the $\tau$ and $\theta$ components concerns the use of the PD model based on collaborative teacher groups working with external support. All stakeholders propose variations of this model, except that the initial government document does not mention external support. The recommendation of a collaborative PD model is also visible in the theory $(\Theta)$ department. Almost all referenced literature that is not Swedish reports on the state of the Swedish mathematics teaching or TIMSS and PISA reports concerns PD of the collaborative type. As has been described by Boesen and colleagues (2015), it is somewhat hard to pinpoint the research base Skolverket (2011) uses to argue for the collaborative model. But it is obvious in the ESO report. Hence, in the subsequent government assignment to the Skolverket that refers to the Eso report, the model described by Timperley (2007) is the main inspiration. 


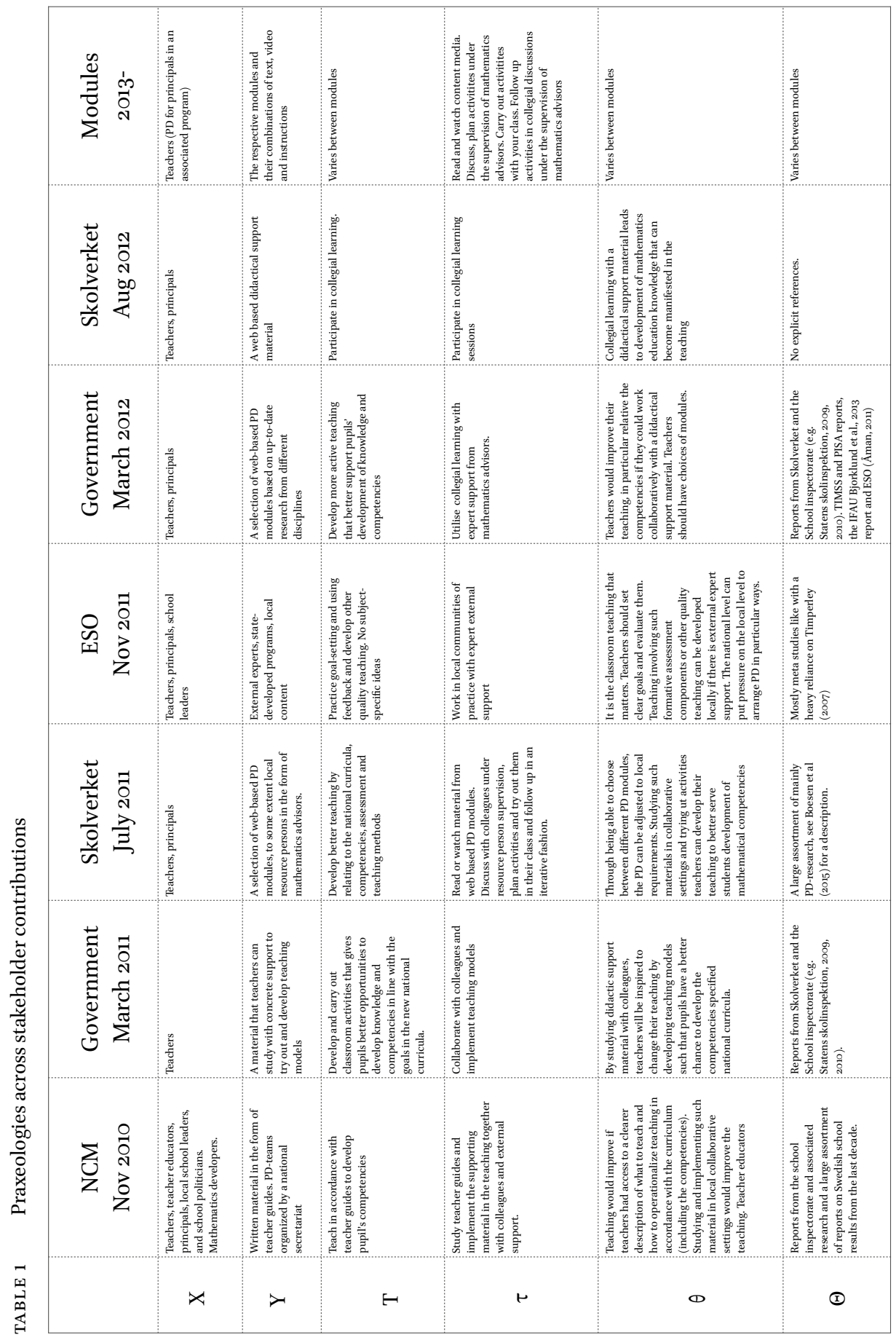


The collaborative PD model recommended by Timperley moves us to where there are differences between stakeholders. While the technology category $(\theta)$ for all stakeholders includes external support, this support is in the form of an expert in the Eso case, which is also the case for NCM. In the Skolverket's interpretation, the resource person is a local teacher with special responsibilities who gets some training within the program, a so-called mathematics advisor. The second analyzed report from the government (Regeringen, 2012) mixes up the expert style support and the Skolverket's suggestion in the same sentence, indicating that the difference is unclear to the government.

The role proposed for the support material $(\mathrm{Y})$ also differs in significant ways between stakeholders. The NCM suggests one specific teacher guide. The government, in its first report, also discussed concrete teaching models. However, subsequent stakeholder contributions shifted the focus from particular teaching models to an increased focus on local choice (in the end, the local choice between modules). This is, in fact, related to an essential difference in the role of the collaborative PD model. In Timperley's (2007) meta-study, the collaborative PD model is a vehicle to implement some specific teaching intervention. But gradually, through the BfM development process and manifested in the Skolverket's goal document and the finished modules, the collegial learning model became a goal in itself and got the role of a container for different sorts of modules content that the developers might choose.

\section{8}

Discussion

The development of the Boost for Mathematics was a multi-stakeholder endeavor. Stakeholders involved in the development process agreed on some program characteristics but not on others. It is probably the case that the Skolverket had the most significant influence over the end product. Still, it is not easy to, even in retrospect, understand the responsibilities of the respective involved stakeholders. A tempting idea might be to try to evaluate the development process in terms of fidelity. Did the Skolverket's work follow the government's intentions? Did the module developers follow the Skolverket's intentions? And so on. But the communicated intentions in the documents I have analyzed are not sharp enough for such an analysis to make sense. The attempt to analyze the stakeholders' contribution as a co-determination system can be seen as a response to embrace the complexity of the development process, which is one of the messages that Century and Cassata (2016) give after reviewing the state of the art of educational implementation research. In a co-determination system, it is perfectly possible and perhaps even required 
(see Section 3.4 in Chevallard, 1992, for a discussion) that different stakeholders have different understandings of the same knowledge object at the same time. By not confronting such dilemmas, ideological differences can be downplayed in the interest of moving forward. That the government in the same sentence continues to refer to external expert support and the in-house educated mathematics advisors is a perfect example.

However, the complexities induced when the development of a PD is a multistakeholder process might also have important downsides. Within the field of implementation research, the case has been made for the importance of a strong theory of change. BfM has been used as an example by mainly describing a misalignment between one of the BfM modules and the Skolverket's intentions (Jankvist et al., 2021). Jankvist and colleagues point out that if a program has no clear theory of change connected to a PD program's overarching goals and intentions, it is hard to know how to evaluate it. The present study can clearly exemplify this. To give an example, let us ponder the collegial learning model employed in BfM. We have already cited Österholm and colleagues (2016) for further use of the collegial learning model employed in BfM based on their evaluation. Also, Ramboll has as the main recommendation to "Keep the professional development model of the Boost for Mathematics in upcoming ventures" (Ramboll, 2016, p. 4, my translation). Given that the research conducted so far shows that the results at the student level are very small or null (Lindvall et al., 2018, 2021), the recommendations to continue to use the model could be challenged.

To understand the context that makes the recommendation rational, let us go back to my analysis. One way of understanding the development process is that it moves from the students' learning and teachers' teaching (implement teaching models, developing students' competencies, etc.) to teachers' and schools' processes (participating in collegial learning, making sure there is a local choice, etc.). As noted, Kirsten and Carlbaum (2020) see BfM as a move away from teacher autonomy. And indeed, if $\mathrm{BfM}$ would have built on a specific teaching model, this might have been the case. In contrast, Prytz (2021) compared BfM with the New Math project in Sweden in the 196os. Prytz described two logics: A, which starts with general hypotheses about teaching that, after iterations and scaleups, is implemented at scale, and B, which starts with research reviews and selections of results followed by a design of an implementation context where teachers eventually themselves complete the implementation. Prytz sees BfM as following model B. This is also my view. The collegial learning model becomes a sort of shell that allows the Skolverket to complete a dual decentralization in the sense that the responsibilities of content are 
decentralized to researchers and teacher educators, and the responsibilities of implementing the innovation are decentralized to teachers. This is perhaps not surprising given that the Skolverket was created in the 1990s in a radical decentralization reform of the Swedish school system (Haldén, 1997). Given this history, the illustrated focus drifts towards teachers' and schools' processes. But it is still the case that the Skolverket could both set their internal goals and have influence over evaluation. The evaluator, Ramboll, devised their own theory of change for their work. One of the long-term goals was that "collegial learning is used continuously and used to develop the teaching and is adapted to local needs" (Ramboll, 2016, p. 31). Still, there are no measurements done to indicate if eventual changes in the teaching lead to better student learning. Therefore, one may argue, it becomes relatively easy to obtain results indicating that the collegial learning model is successful.

What about the research base for BfM, then? Recall that Swedish education by law should rest on research (and proven experience). Not considering the varying research base for different modules, it is the PD model itself, the collegial learning model, that we can examine. Boesen and colleagues analyzed most of the documents I have analyzed and concluded that while the argumentation for the design decisions in BfM was somewhat weak, the resulting design on a general level coincided with recommendations from state-of-theart PD research (Boesen et al., 2015). In the present study, I looked closer at the $\mathrm{BfM}$ research base and found several ways BfM breaks with the research it is said to build on. Let us look closer at Timperley's meta-study (2007), which is the main research base for the collaborative PD model. While collaborative teacher development with external expert support is an innovation from general pedagogy rather than mathematics education, Timperley's report deals with mathematics separately. So how is this innovation implemented in BfM? First, none of the studies Timperley refers to are anywhere near the size of BfM. So it is completely unsurprising that the Skolverket had to relax the conditions of external expert support and replace it with mathematics advisors educated "in-house." It is, however, surprising that the choice of relaxing the conditions of expert support is never problematized. It slides through, so to say, despite that, one can hardly say that the collegial learning model is the same one that builds on the research Timperley summarizes.

A further important fact is that Timperley bases her conclusions on studies that are in themselves implementation studies. Some innovation is conveyed to teachers in some particular way and then implemented in classrooms. In the end, she observes that one particular way of conveying innovation to teachers, namely the collaborative model with expert support, seems likely to succeed, 
that is, lead to a change in the teaching that is lasting and has an effect on students. But every study still has an innovation, or at least a particular pedagogical idea, as its base. Nothing indicates that the collaborative model in the form of an empty shell would continue to deliver. In BfM, the collegial learning model became foregrounded. In most cases, it is fair to say that the modules do not convey any particular innovation.

\section{9}

\section{Conclusion}

In the present paper, I have examined a PD program where the researchers themselves are the primary implementers but the state. The PD effort has to be implemented in the milieu of the complicated institutional structure that involves the governmental system, school system, and university system structures. This creates a sort of parallelism, where several stakeholders understand what is to be created differently. To account for the shifts of attention and intention of different stakeholders, I analyzed the creation of BfM as a diversity of praxeologies - a co-determination system. Through this theoretical lens, I could follow how what the teachers should actually do and how they should do it in the PD shifted between construction stages. But also how the ideas on why and for what purpose teachers should do those things shifted. I discussed how the distributed way of construction BfM seems to have led to, or at least allowed, the intentions of building a research-based PD to break down.

In line with Cobb and Jackson (2O21) in the previous issue of IRME, I believe that large-scale PD must be firmly connected to all aspects of the educational system.

It may also be a good idea to involve a multitude of stakeholders early in the development of large-scale PD programs or a program involving other types of pedagogical innovations. Such a practice might tap into dimensions of knowledge that no individual stakeholder might have and help anchor the program across different involved practices. However, the analysis of the case examined here shows that there are certainly also risks. If the responsibility of the development is shared between stakeholders, no one might take an overarching responsibility. Without a well-thought-out theory of change, it will be tough to evaluate a program in a way that can inform the design of future programs. Century and Cassata (2016) write that "implementation research is an endeavor to understand better whether the field of education research is accomplishing its goal" (p. 170). Did BfM accomplish its goal? No, if you look at results on the student level. But other than that, it may depend on who you ask. 


\section{References}

Åman, J. (2011). Att lära av de bästa: En ESO-rapport om svensk skola i ett internationellt forskningsperspektiv [Learning from the best: An ESO report on Swedish schools in an international research perspective] (2011:8). Expertgruppen för Studier i Offentlig Ekonomi.

Bergmark, U. \& Hansson, K. (2021). How teachers and principals enact the policy of building education in Sweden on a scientific foundation and proven experience: Challenges and opportunities. Scandinavian Journal of Educational Research, 65(3), 448-467. https://doi.org/10.1080/oo313831.2020.1713883.

Bergqvist,E.,Bergqvist,T., Boesen,J.,Helenius, O.,Lithner,J.,Palm,T.\&Palmberg,B.(2010a). Matematikutbildningens mål och undervisningens ändamålsenlighet. Grundskolan. Våren 2009 [Aims of mathematics education and the appropriateness of teaching. Primary and lower secondary school. Spring of 2009]. National Center for Mathematics Education.

Bergqvist, E., Bergqvist, T., Boesen, J., Helenius, O., Lithner, J., Palm, T. \& Palmberg, B. (2010b). Matematikutbildningens mål och undervisningens ändamålsenlighet. Gymnasieskolan. Hösten 2009 [Aims of mathematics education and the appropriateness of teaching. Upper secondary school. fall 2009]. National Center for Mathematics Education.

Björklund, A., Fredriksson, P., Gustafsson, J.-E. \& Öckert, B. (2013). Den svenska utbildningspolitikens arbetsmarknadseffekter: Vad säger forskningen? [The labor market effects of Swedish education policy: What does the research say?] (2010:13; Rapport). Institutet för Arbetsmarknads-och Utbildningspolitisk Utvärdering (IFAU).

Boesen, J., Helenius, O., Bergqvist, E., Bergqvist, T., Lithner, J., Palm, T. \& Palmberg, B. (2014). Developing mathematical competence: From the intended to the enacted curriculum. The Journal of Mathematical Behavior, 33, 72-87. https://doi.org/10.1016/ j.jmathb.2013.10.001.

Boesen, J., Helenius, O. \& Johansson, B. (2015). National-scale professional development in Sweden: Theory, policy, practice. ZDM Mathematics Education, 47(1), 129-141. https://doi.org/10.1007/s11858-014-0653-4.

Century, J. \& Cassata, A. (2016). Implementation research: Finding common ground on what, how, why, where, and who. Review of Research in Education, 4o(1), 169-215. https://doi.org/10.3102/oog1732X16665332.

Chevallard, Y. (1992). A theoretical approach to curricula. Journal Für MathematikDidaktik, 13(2-3), 215-23o. https://doi.org/10.1007/BFo3338779.

Chevallard, Y., Bosch, M. \& Kim, S. (2015). What is a theory according to the anthropological theory of the didactic? In K. Krainer \& N. Vondrová (Eds.), Proceedings of the Ninth Congress of the European Society for Research in Mathematics Education (2614-2620). Charles University in Prague; Faculty of Education; E RME. 
Chevallard, Y. \& Sensevy, G. (2014). Anthropological Approaches in Mathematics Education, French Perspectives. In S. Lerman (Ed.), Encyclopedia of mathematics education (pp. 38-43). Springer. https://doi.org/10.1007/978-94-0o7-4978-8_9.

Cobb, P. \& Jackson, K. (2021). An empirically grounded system of supports for improving the quality of mathematics teaching on a large scale. Implementation and Replication Studies in Mathematics Education, 1(1), 77-110. https://doi.org/ 10.1163/26670127-01010004.

Desimone, L. M. (2009). Improving impact studies of teachers' professional development: Toward better conceptualizations and measures. Educational Researcher, 38(3), 181-199. https://doi.org/10.3102/o013189Xo8331140.

Haldén, E. (1997). Ett centralt ämbetsverk $i$ omvandling - Från Skolöverstyrelsen till Skolverket [A central agency in transformation - From the National Board of Education to the National Agency for Education]. Stockholm Center for Organizational Research.

Hill, C. J., Bloom, H. S., Black, A. R. \& Lipsey, M. W. (2008). Empirical benchmarks for interpreting effect sizes in research. Child Development Perspectives, 2(3), 172-177. https://doi.org/10.1111/j.1750-86o6.2008.0oo61.x.

Jankvist, U. T., Aguilar, M. S., Dreyøe, J. \& Misfeldt, M. (2019). Adapting implementation research frameworks for mathematics education. In U. T. Jankvist, M. Van den Heuvel-Panhuizen \& M. Veldhuis (Eds.), Proceedings of the Eleventh Congress of the European Society for Research in Mathematics Education (4405-4412). Freudenthal Group \& Freudenthal Institute; Utrecht University; ERME.

Jankvist, U. T., Gregersen, R. M. \& Lauridsen, S. D. (2021). Illustrating the need for a 'Theory of Change' in implementation processes. ZDM Mathematics Education. https://doi.org/10.1007/s11858-021-01238-1.

Kennedy, M. M. (2016). How does professional development improve teaching? Review of Educational Research, 86(4), 945-98o. https://doi.org/10.3102/o0346543156268oo.

Kirsten, N. \& Carlbaum, S. (2020). Kompetensutveckling för professionella lärare? Introduktionen av kollegialt lärande i svensk skola [Competence development for professional teachers? The introduction of collegial learning in Swedish schools]. Pedagogisk Forskning i Sverige, 25(1), 7-34. https://doi.org/10.15626/pfs25.01.01.

Latour, B. (2005). Reassembling the social: An introduction to actor-network-theory. Oxford University Press.

Lauridsen, S. D. \& Gregersen, R. M. (2017). Implementering af matematikdidaktiske forskningsresultater i praksis: Et casestudie af to moduler fra det svenske Matematiklyft [Implementation of mathematics education research results in practice: A case study of two modules from the Swedish Boost for Mathematics] [Unpublished master's thesis]. Aarhus University.

Lindvall, J., Helenius, O. \& Wiberg, M. (2018). Critical features of professional development programs: Comparing content focus and impact of two large-scale programs. Teaching and Teacher Education, 70, 121-131. https://doi.org/10.1016/j.tate.2017.11.013. 
Lindvall, J., Helenius, O., Eriksson, K. \& Ryve, A. (2021). Impact and design of a nationalscale professional development program for mathematics teachers. Scandinavian Journal of Educational Research. https://doi.org/10.1080/00313831.2021.1910563.

Marton, F. \& Booth, S. A. (1997). Learning and awareness. Routledge.

Mason, J. (2002). Researching your own practice: The discipline of noticing. Routledge.

McIntosh, A. (2008). Förstå och använda tal: En handbok [Understanding and using number: A handbook]. Nationellt Centrum för Matematikutbildning.

Österholm, M., Bergqvist, T., Liljekvist, Y. \& van Bommel, J. (2016). Utvärdering av Matematiklyftets resultat: Slutrapport [Evaluation of the results of the Boost for Mathematics: Final report]. https://www.skolverket.se/getFile?file=3706.

Ostermeier, C., Prenzel, M. \& Duit, R. (2010). Improving science and mathematics instruction: The sINUs project as an example for reform as teacher professional development. International Journal of Science Education, 32(3), 303-327. https://doi .org/10.1080/0950069o8o2535942.

Prytz, J. (2021). When research met policy: A history of innovation and a complicated relationship in three Swedish development projects in mathematics education, 196o-2018.ZDMMathematicsEducation. https://doi.org/10.1007/s11858-021-01247-o.

Ramboll. (2016). Utvärdering av matematiklyftet 2013-2016 [Evaluation of the Boost for Mathematics 2013-2016]. Ramboll. https://www.skolverket.se/getFile?file=3705.

Regeringen. (2011). Uppdrag till Statens skolverk att stärka undervisningen i matematik, naturvetenskap och teknik [Assignment to the National Agency for Education to strengthen teaching in mathematics, science and technology] (U2011/2229/GV; pp. 1-5). Regeringen.

Regeringen. (2012). Regeringsbeslut. Uppdrag attsvara för utbildning [Government decision. Assignment to be responsible for education]. (U2012/2103/GV). Regeringen.

Skolverket. (2011). Delredovisning av uppdrag om att stärka undervisningen i matematik, naturvetenskap och teknik [Partial report on assignment to strengthen teaching in mathematics, science and technology] (Dnr 2011:643). Skolverket.

Skolverket. (2012a). Beslut: Matematiklyftet [Decision: The Boost for Mathematics]. Skolverket.

Skolverket. (2012b). Delredovisning av uppdrag om att svara för utbildning DNR 2011:643 [Partial reporting of assignment to be responsible for education DNR 2011: 643]. Skolverket. https://www.skolverket.se/getFile?file=2896.

Statens Skolinspektion. (2009). Undervisningen i matematik - Undervisningen innehåll och ändamålsenlighet [Teaching mathematics - Teaching content and appropriateness] (2009:5). Statens Skolinspektion.

Statens Skolinspektion. (2010). Undervisningen i matematik i gymnasieskolan [The teaching of mathematics in upper secondary school] (2010:13). Statens Skolinspektion.

Stein, M. K., Engle, R. A., Smith, M. S. \& Hughes, E. K. (2008). Orchestrating productive mathematical discussions: Five practices for helping teachers move beyond 
show and tell. Mathematical Thinking and Learning, 10(4), 313-340. https://doi .org/10.108o/10986o6o8o2229675.

Sterner, G. \& Helenius, O. (2015). Number by reasoning and representations - the design and theory of an intervention program for preschool class in Sweden. In O. Helenius, A. Engström, T. Meaney, P. Nilsson, E. Norén, J. Sayers \& M. Österholm (Eds.), Development of Mathematics Teaching: Design, Scale, Effects. Proceedings of MADIF 9. The Ninth Swedish Mathematics Education Research Seminar Umeå, February 4-5, 2014 (pp. 159-168). Swedish Society for Research in Mathematics Education.

Sterner, G., Helenius, O. \& Wallby, K. (2014). Tänka, resonera och räkna iförskoleklassen [Thinking, reasoning and counting in the preschool class]. Nationellt Centrum för Matematikutbildning (NCM).

Sterner, G., Wolff, U. \& Helenius, O. (2020). Reasoning about representations: Effects of an early math intervention. Scandinavian Journal of Educational Research, 64(5), 782-80o. https://doi.org/10.108o/oo313831.2019.1600579.

Timperley, H., Wilson, A., Barrar, H. \& Fung, I. (2007). Teacher professional learning and development: Best evidence synthesis iteration. Ministry of Education of New Zealand.

Utbildningsdepartementet. (2004). Att lyfta matematiken - intresse, lärande, kompetens [To raise mathematics - interest, learning, competence] (Statens Offentliga Utredningar sOU 2004:97). Utbildningsdepartementet. https://www.regeringen .se/49b71d/contentassets/1eo3188c1e5440oab455a6245cbc17de/att-lyfta-matemati ken-intresse-larande-kompetens-sou-200497.

Wayne, A. J., Yoon, K. S., Zhu, P., Cronen, S. \& Garet, M. S. (2008). Experimenting with teacher professional development: Motives and methods. Educational Researcher, 37(8), 469-479. https://doi.org/10.3102/oo13189Xo8327154.

Witzel, B. S., Mercer, C. D. \& Miller, M. D. (2003). Teaching algebra to students with learning difficulties: An investigation of an explicit instruction model. Learning Disabilities Research \& Practice, 18(2), 121-131. 